\title{
KBBIJAKAN TRANSPORTASI PEMERINTAH KOTA PADANG DALAM MENGATASI KEMACETAN LALU LINTAS DI KAWASAN BUNDARAN AIR MANCUR PASAR RAYA PADANG
}

\author{
SKRIPSI \\ Díajukan untuk Mencapai Gelar Sarjana IImtu Politik \\ Pada Fakultas Imnu Sosial dan IImu Politik Universitas Andalas
}

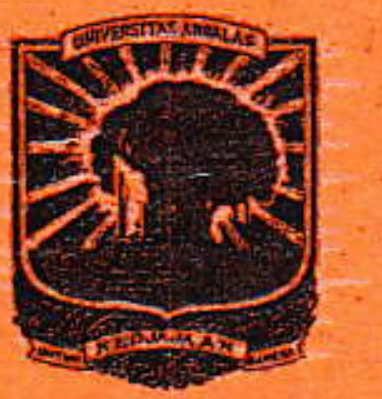

JURUSAN ILMU POLITIK

FAKULTAS ILMU SOSIAL DAN ILMU POLITIK

UNIVERSITAS ANDALAS

PADANG

2010 


\section{ABSTRAK}

\section{Dewi Dahlan. 06193075. Skripsi. Kebijakan Transportasi Pemerintah Kota Padang Dalam Mengatasi Kemacetan Lalu Lintas Di Kawasan Bundaran Air Mancur, Pasar Raya Padang. Jurusan Ilmu Politik, Fakultas Ilmu Sosial dan Ilmu Politik Universitas Andalas. Pembimbing I Drs. Syaiful M.Si,
Pembimbing II Roni Ekha Putera S.IP, M.PA}

Kepadatan lalu lintas yang meningkat dengan cepat akhir-akhir ini di berbagai kota di Indonesia telah menimbulkan kemacetan lalu lintas yang cukup hebat. Salah satunya adalah Kota Padang. Salah satu kawasan yang mengalami kemacetan lalu lintas tersebut adalah kawasan Bundaran Air Mancur, Pasar Raya
Padang.

Penelitian ini bertujuan untuk mengetahui dan mendeskripsikan kebijakan transportasi Pemko Padang untuk mengatasi kemacetan lalu lintas di kawasan Bundaran Air Mancur, Pasar Raya Padang. Lokasi yang diambil sebagai bahan kajian adalah Bundaran Air Mancur, Pasar Raya Padang dengan menggunakan metode kualitatif deskriptif dan teknik pemilihan informan secara purposive sampling. Sebagai bahan rujukan maka penelitian ini menggunakan 19 buku teori, 8 buku metode, 5 buah jurnal dan 8 situs. Bila dikaitkan dengan aspek transportasi yang dikemukakan oleh Le Grand, Julian dan Ray Robinson yang menyatakan ada 4 aspek utama yang ada dalam melihat transportasi perkotaaan yaitu availability, quality, accessibility, dan price maka Pemerintah Kota Padang sudah mengeluarkan beberapa kebijakan namun belum memenuhi keempat kategori di
atas.

Dari hasil penelitian ini dapat disimpulkan bahwa kebijakan resmi yang dikeluarkan Pemko Padang dalam bidang transportasi hanya mengatur masalah harga (price). Aspek lainnya seperti availability, accessibility dan quality belum menjadi perhatian serius oleh para pengambil kebijakan transportasi. Pemerintah Kota Padang memberikan otonomi kepada Dinas Perhubungan untuk mengatur permasalahan operasional transportasi yang ada di Kota Padang termasuk di Bundaran Air Mancur berdasarkan Peraturan Walikota Nomor 31 tahun 2008, Dinas Perhubungan mempunyai salah satu tugas manajemen dan rekayasa lalu lintas. Oleh sebab itu Dinas Perhubungan berhak mengeluarkan kebijakan khusus tanpa melalui persetujuan Walikota bersama DPRD. Kebijakan yang dikeluarkan oleh Dinas Perhubungan untuk mengatasi kemacetan lalu lintas di Bundaran Air Mancur adalah sistem kanalisasi. Dalam kebijakan ini Dinas Perhubungan sebagai leading sector transportasi telah membuat pemisahan jalur angkutan kota dan jalur kendaraan pribadi di sekitar kawasan tersebut. Namun sistem ini hanya berfungsi untuk melewatkan jalur kendaraan saja, sementara itu aspek lainnya tidak dipertimbangkan. Kanalisasi yang dibuat khusus ini sebetulnya sudah mempertimbangkan aspek availability. Sistem ini telah berjalan selama satu tahun, namun tidak mampu mengatasi kemacetan lalu lintas di kawasan Bundaran Air Mancur. Permasalahan kemacetan lalu lintas ini bertambah parah karena tidak adanya koordinasi dan lepas tanggung jawab antar dinas terkait. Jika hal ini terus terjadi kemacetan lalu lintas di kawasan Bundaran Air Mancur tidak akan pernah teratasi dan mungkin akan menyebar ke kawasan-kawasan lainnya.

Kata Kunci: Kebijakan Transportasi, Kemacetan Lalu Lintas, Kanalisasi 


\section{$\mathrm{BAB}$ I}

\section{PENDAHULUAN}

\subsection{Latar Belakang}

Transportasi merupakan bagian yang integral dalam kehidupan masyarakat. Ia tumbuh dan berkembang seiring dengan perkembangan peradaban manusia. Pengembangan teknologi transportasi yang baru akan menyebabkan terjadinya perubahan dalam masyarakat pengguna teknologi tersebut. Perubahan yang terjadi pada masyarakat menyebabkan timbulnya kebutuhan terhadap pengembangan transportasi yang baru. Demikian terus menerus hal ini terjadi sebagai suatu sebab akibat.

Keinginan orang untuk berpindah dan kebutuhan mereka akan sesuatu yang lain (belajar, bekerja, berbelanja atau mengunjungi teman) telah menciptakan suatu kebutuhan akan transportasi. Secara prinsip, orang tidak perlu berpindah jika segala kebutuhannya dapat dipenuhi di tempat dia berada. Hal ini mustahil karena setiap tata guna lahan mempunyai persyaratan teknis tersendiri. Akibatnya lokasi kegiatan tersebut tersebar secara heterogen di dalam ruang yang ada yang selanjutnya menyebabkan perlu adanya pergerakan yang digunakan untuk proses pemenuhan kebutuhan'.

Dalam hal ini transportasi berfungsi sebagai penghubung antara orang dengan tata guna lahan, pengikat kegiatan dan memberikan kegunaan tempat dan waktu untuk komoditi yang diperlukan. Dengan adanya transportasi orang akan dapat berpindah dari satu tata guna lahan ke tata guna lahan yang lain seperti dari

1 Diktat Jurusan Teknik Sipil, Dasar-Dasar Rekayasa Transportasi, Fakultas Teknik Universitas Andalas, Padang, 2006, hlm. 4. 
pemukiman ke pasar, tempat kerja dan tempat lainnya melalui suatu jaringan transportasi.

Menurut Le Grand, Julian dan Ray Robinson ada empat aspek utama dalam melihat permasalahan transportasi yaitu ketersediaan (availability) artinya sejauh mana sistem transportasi dapat memenuhi kebutuhan. Kedua adalah kualitas (quality) sejauh mana suatu sistem transportasi dapat menyediakan layanan yang dapat menjawab kebutuhan dan harapan. Ketiga akses (accessibility) yaitu sejauh mana sistem transportasi mampu dijangkau oleh publik. Keempat harga (price) yaitu harga yang harus dibayar untuk memenuhi kualitas pelayanan transportasi yang memadai ${ }^{2}$. Semua aspek ini terintegrasi dalam suatu masalah pertransportasian ketika kebijakan yang ada tidak mendukung keempat aspek transportasi tersebut. Kendala utama yang akan ditimbulkan dari masalah ini adalah aktivitas ekonomi publik, seperti pergi ke tempat kerja, menjadi terganggu akibat terjadinya traffic jam, kemacetan lalu lintas yang hebat.

Permasalahan transportasi di Indonesia sudah semakin kompleks. khususnya di beberapa kota besar seperti DKI Jakarta, Surabaya, Medan dan Bandung ${ }^{3}$. Kota berpenduduk padat bisa dipastikan mempunyai permasalahan transportasi. Kondisi ini terjadi karena pada hakikatnya setiap manusia melakukan pergerakan (trip) untuk memenuhi kebutuhan hidupnya ${ }^{4}$. Untuk daerah perkotaan, masalah transportasi yang selalu terjadi adalah bagaimana memenuhi permintaan

\footnotetext{
${ }^{2}$ Le Grand, Julian dan Ray Robinson, The Economics of Social Problems, N Y, Palgrave, 1992. hlm. 2.

${ }^{3}$ Fanin Nurlita Nainggolan, 2003, Manajemen Kebutuhan Transportasi (MKT) scbagai Alternatif Penanggulangan Problematika Transportasi Pusat Kota Medan, Jurnal Universitas Sumatera Utara, Bulletin.Penataan ruang.net/upload/data) diakses tanggal 13 November 2009 jam 17.I5. hlm. i.

"lbid.
} 


\section{BAB VI}

\section{KESIMPULAN DAN SARAN}

\subsection{Kesimpulan}

1. Kebijakan transportasi Kota Padang untuk mengatasi kemacetan lalu lintas di kawasan Bundaran Air Mancur hanya mengandalkan Undang-Undang No 22 tahun 2009 tentang lalu lintas dan angkutan jalan. Pemerintah Kota Padang tidak membuat kebijakan khusus di Bundaran Air Mancur, walaupun daerah ini mempunyai karakteristik yang berbeda dengan daerah lainnya yang juga mengalami kemacetan lalu lintas. Kebijakan yang terlalu umum ini dianggap sebagai pemicu terjadinya kemacetan di kawasan tersebut. Pemerintah Kota Padang hanya mengandalkan Dinas Perhubungan sebagai pembuat kebijakan utama dalam bidang lalu lintas berdasarkan SK Walikota No 31 tahun 2009 tentang tugas pokok dan fungsi Dinas Perhubungan.

2. Ditinjau dari aspek Availability, kebijakan transportasi Pemko Padang telah menghadirkan sistem kanalisasi sebagai kebijakan utama untuk mengatasi kemacetan lalu lintas di Bundaran Air Mancur namun sering mengalami pelanggaran. Rute yang terkonsentrasi di Bundaran Air Mancur, lahan parkir yang disewakan kepada pedagang kaki lima ikut memperparah kemcetan yang terjadi di kawasan Bundaran Air Mancur.

3. Ditinjau dari aspek Quality, kebijakan transportasi Pemko Padang belum mampu menghadirkan sistem pertransportasian yang dapat menjawab harapan masyarakat. Hal ini dilihat dari ketiaadaan terminal angkutan kota 


\section{DAFTAR PUSTAKA}

Abdul Wahab, Solichin. 1997. Analisis Kebijaksanaan (Dari Formulasi Ke Implementasi Kebijaksanaan Negara), Jakarta: PT Bumi Aksara.

Afrizal, MA. 2005. Pengantar Metode Penelitian Kualitatif(Dari Pengerian Sampai Penulisan Laporan. Padang: Laboratorium Sosiologi Fakultas Ilmu Sosial dan Ilmu Politik Universitas Andalas.

A.G. Subarsono. 2005. Analisis Kebijakan Publik. Yogyakarta: Pustaka Pelajar.

Abbas, Ardi.Masalah Transportasi Kota Padang. Padang: Fakultas IImu Sosial dan Ilmu Politik Universitas Andalas.

Ayu, Meta Sekar. 2009. Manajemen Transportasi Kota Padang (Studi tentang Koordinasi antar Instansi dalam Mengatasi Kemacetan di sekitar Bundaran Air Mancur Pasar Raya Padang). Skripsi tidak untuk dipublikasikan. Padang: Fakultas Ilmu Sosial dan Ilmu Politik Universitas Andalas.

Diktat Jurusan Teknik Sipil. 2006. Dasar-Dasar Rekayasa Transportasi. Padang: Fakultas Teknik Universitas Andalas.

Budihardjo, Eko. 1997. Lingkungan Binaan dan Tata Ruang Kota. Yogyakarta: Andi Yogyakarta.

Bungin, Burhan. 2001. Metodologi Penelitian Kualitatif (Aktualisasi Metodologis ke Arah Ragam Varian Kontemporer). Jakarta: PT Raja Grafindo Persada.

Faisal, Sanafiah, 1990. Penelitian Kualitatif. Dasar-Dasar dan Apikasi. Malang: YA3.

Febrianti. 2005. Pedagang Pasar Raya Protes Pendirian Mal, (online). (http:// www.tempointeractive. com/hg/musa/sumatera), diakses 11 November 2009.

Harrison, Lisa. 2007. Metode Penelitian Politik. Jakarta: Kencana.

Hauser, M Philip dkk, 1985. Penduduk dan Masa Depan Perkotaaan. Jakarta: Yayasan Obor Indonesia.

Gabriel Lele, 1999. Postmodernisme Dalam Pengembangan Wacana Formulasi Kebijakan, dalam JSP Jurnal Fakultas Ilmu Sosial dan Ilmu Politik Universitas Gadjah Mada.Vol 3. No 2.

Jinca, M. Y. Peran Profesi Transportasi Dalam Penataan Ruang, (Online). (http://bulletin. penataan ruang. net/upload/ data) diakses 13 November 